\title{
Critical Slag / Critical Slog
}

Literary criticism is a subject I get asked to talk about several times a year, whether in print or live. I gave the Times Literary Supplement lecture about it - which left barely an open eye in the house - at last year's Sydney Writer's Festival and I wrote about it, quite separately, in the Australian a month or two later. So please don't blame me if I show signs of battle fatigue or if I make you want to scream with boredom.

So why, you may ask, have I called this piece 'Critical Slag/Critical Slog'. What grim tale hangs by that vowel shift?

Well, let's take the slag first. The kind of literary criticism which I practice, the shirtsleeves literary criticism of a practising critic who spends his time reviewing books - reading them and writing about them - involves the nearly archaic art of evaluation. In academic circles this is sometimes viewed less as a heresy than a primitive belief streaming from a radically naïve understanding of the process of literary production, the process by which literature is constructed.

It is, after all, forty-five years or so since Northrop Frye articulated his critique of value in his Anatomy of Criticism and a generation or so since the universities (in the wake of the Theory Germ) started to relativise their sense of the canon and to realise that there were a lot more books than Leavis would give standing room in his Calvinist canon that could keep a reader's attention and a lot more cultural objects (films, television, cartoons) that could become objects of cultural and critical scrutiny.

Well, from a practising literary critic's point of view, reviewing a book, none of this counts for much. It's the critic's business to say how good she thinks a book is. If she wants to be self-conscious about this, she can attribute her choices to the fact that she's a tertiary-educated lesbian mother of four with a taste for bodice rippers, but at the end of the day no one is interested.

No one is interested in whatever biographical irrelevancies helped to form the subject position of the critic that is, by implication, being inserted.

The critic may indulge in this by way of modesty or narcissism, but who cares? What you want from a critic is not taste but judgment. I've said this a thousand times before, but I'll say it again: I have no taste for Murray Bail novels about gum trees or for scarifying novels of schadenfreude and sexual abasement like The Piano Teacher by this year's Nobel Prize winner Elfriede Jelinek.

I think these books are good; I think they have a power and a truth which has nothing to do with what happens to divert me. I can tell you what I have a taste for. I have a taste for Michael Innes detective stories in which Appleby 
the Scotland Yard detective quotes Aeschylus. It has nothing to with what happens when I read a novel like Sonya Hartnett's Of a Boy or J.M. Coetzee's Elizabeth Costello. And don't be too quick to say that what I am describing as judgment is merely the idealisation of taste. Judgment, of course, tallies with one of the ways we use language: 'Did you like it?' we ask. But don't be misled by this. Germaine Greer is right when she says that although literature is subjectively apprehended it's not hard to find people who agree with you. We tend to respond to literature normally I think. We respond to it, or we should, the way musical people respond to piano playing. In one way, at least when it comes to ascertaining how skilled a piece of writing is, what claims it has to aesthetic significance as something which is true - I'm deliberately involving the reverberation of loaded terms here - will, at least in minimal terms, be clear from the outset. More or less. Yes, Gide was wrong about Swann's Way but, despite glaring exceptions, people who can tell, can tell.

This is not to say that there won't be considerable areas of legitimate disagreement of the 'Bellow's better than Updike' variety, but I think the kind of consensus that can be established by people who know what they're talking about is much more remarkable than the extent of disagreement.

Let's take something in the area of poetry. I happen to think that the verse novels of the Canadian poet Ann Carson - Autobiography of Red and The Beauty of the Husband - are masterpieces. They seem to me to be not only what passes for poetry of the highest order but also a rung above that. I think they command the attention of any intelligent reader in the way the very best fiction - that of De Lillo, say - does. And then, above that, there is this extraordinary curvaceousness and economy of literary form. Now this opinion of mine happens to be something I share, more or less independently, with Susan Sontag and Harold Bloom and Gary Davenport and Owen Richardson and Steven Armstrong of the Playbox Theatre.

Why wouldn't it be? I imagine it may be shared by a few more people since I have been writing about her but I don't think there is any mumbo-jumbo or mystique of authority involved in that. I don't imagine that anyone thinks, 'Oh, Susan Sontag and Peter Craven think this Carson woman is pretty good so even though reading her for me is like chewing glass I'm going to tell myself I like it.' I mean why in the name of God would that happen?

This is not to deny that any kind of writing can be sold like soap and that some fraction of people involved in the business of marketing literature are essentially soap sellers (who wouldn't know one end of a book from another) and that this involves all sorts of dangers to significant writing (not least the coming together - surprise, surprise - of commercial imperatives with good old relativism.)

I suspect that in the last however many years people in universities have become confused about all this because (for more or less legitimate reasons) they have become obsessed with looking at the business of literary production, at looking at how books are produced and marketed and sold in material terms.

This can lead everyone down the track of a false or factitious epistemology or, at any rate, trail of causation. It can all seem like the question of why is he a great interviewer: is it because he's good-looking, is it because he went to such and such a university, or is it that his sister is married to X. Is it because he's photogenic and looks good on TV? All these things may be materially true - and yes, it's probably also true that he couldn't have done the interview without an alarm clock - and yet that can all be by the bye. 
My own route into literary journalism, if you're interested, is that I went back to university in the late 70 s with the idea of pursuing an academic career, but I became distracted from this (while I was a postgraduate) by editing the literary magazine Scripsi, which published quite a range of international writing and criticism.

Although I subsequently spent a little time teaching in universities for the odd pittance here and there, I was never a career academic. But my own intellectual background (which I suppose had something to do with the Garners and Carvers and Ashberys and Sontags and Blooms being in Scripsi) is obviously pertinent to the career I pursued as a critic.

When we put Scripsi together in the early 80 s and maintained it for the next dozen years or so, that magazine represented some sort of evaluative consensus. It was in a sense a regrouping of diverse voices, some of whom had fellow-travelled with what we might call the relative relativisms.

It's significant, I suppose, that two of the Americans we published, Susan Sontag and Harold Bloom, have become voices that speak on behalf of the idea of value despite her pluralism and his kicking against the old Eliotic/Leavisite canon.

I could talk about these matters forever and leave everybody marvellously unenthralled.

The job of a critic is to say how good a book is. If he is excessively selfconscious or unsure of himself, he may have recourse to saying that he's a wheat farmer with a taste for rugby, porcelain and bondage in the hope that this may qualify everyone's sense of his right to speak. But if you ask me, why bother?

In practice the way we describe books will not necessarily vary greatly whether we think literature is a timeless order modified by every subsequent work of literature, as T.S. Eliot did, or whether we think that literature or literary writing is a construct that simply fans the flame of the sectional interests of a given camp of people (more or less defined in class terms) who keep it alive.

Personally, I think the latter view is preposterously jejune and that it represents an extraordinary betrayal of the people who cry for what literature can give them as if they were crying for bread.

It appalls me that my own hippie generation, out of nothing but inverted snobbery, turned its back in the high schools (and to some extent in the universities) on what Bernard Shaw was not wrong to say was the thing that divided soul from soul and class from class.

Owen Richardson said recently in the Age that Graham Greene was the last major English novelist to write for a mass market. I don't know if that's true, but it's a sobering thought if it is. What we have seen in the last decade or two is the rise of a category of writing that might be described as chic or highbrow trash - the kind of thing, like James Lee Burke's detective stories, that appeals to the literate and literary reader but is not itself literary in its ambitions, or only ambiguously so. Shane Maloney is our own shining star in this field. I have no categorical objection to this stuff except that I think it's important to acknowledge that it's our trash.

We have also seen the rise of a kind of writing - oh so ambitious in its ambitions and oh so confidently marketed - that is literary in its ambitions but 
shoddy in its performance. It has a hopeful tilt towards hypothetical literary greatness and it represents the work of writers who don't know their craft. I happen to think that both Richard Flanagan in Gould's Book of Fish and Eliot Perlman's Seven Types of Ambiguity are in this category. My published opinions of these books are, I suppose, notorious slags.

What is the justification of the slag? First of all, it tries to tell the truth in a timid field. Secondly - and this is some validation even when you disagree with a critic - the slag will tend to throw a critic back on first principles as he attempts to explain how a book that fails, fails to realise its own manifest ambitions. So Gould's Book of Fish is an attempt at a highly coloured magical realism, but it too often refers rather than presents, the narrative voice is naive, and it is incapable of sustaining its own attempts at parodic or purple effects.

And so it goes. I suppose, slag or praise, it must be obvious that all of this involves some sort of slog. In a given week I might write a full dress piece of several thousand words about Shakespeare or Naipaul for the Financial Review or the Review section of the Age. In a good week I might review a book or two in 1000 or 1200 words. Every so often that might also involve writing three or four of my short pieces for my Sunday Age column about literary classics.

In most weeks I might also write something about film or television that might or might not have a literary hook, because critics are to some extent creatures of their moments in time.

I happen to have journalism in my blood - my father was a sportswriter - and I have old-fashioned hack skills - I can write fast.

Temperamentally and by affinity I am a theatre critic as much as I am a literary critic, and I am about to commence a stint writing a weekly TV column: ever since McLuhan we old cultural tories like to be let loose on popular media.

As it happens I read slowly - I could gut a novel in a night - but I read, sometimes aloud, for what Barthes called the grain of the voice, for literary quality, for cadence, almost as if I was reading poetry.

Maybe it's the homage seriousness pays to hack work. Who knows?

Peter Craven is one of Australia's foremost literary critics. His literary journalism has appeared widely in major Australian and overseas magazines and newspapers. He was an editor of Scripsi, the inaugural editor of Quarterly Essay and founding editor of Black Inc's annual Best Australian Poems, Best Australian Stories and Best Australian Essays. 
Editors: Wenche Ommundsen and Maria Takolander

General Editors: Nigel Krauth \& Jen Webb

Text@griffith.edu.au 